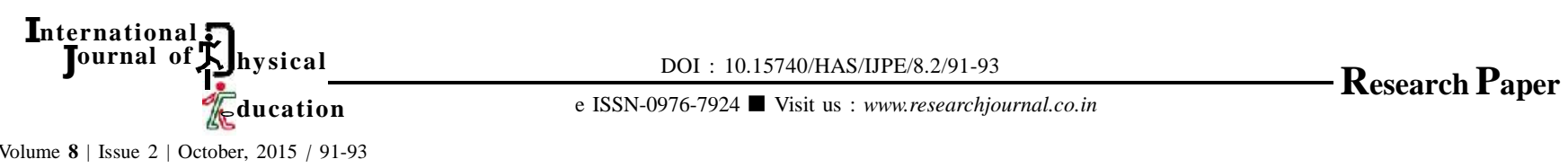

\title{
A comparative study of rural and urban high-school boys attitude towords physical education and sports of Haveri disrtict
}

\section{BASANANGOUDA LAXMESHWAR}

Received : 13.04.2015; Revised : 22.08.2015; Accepted : 25.09.2015

Author for correspondence

BASANANGOUDA

LAXMESHWAR

University College of Physical

Education, Bangalore University,

BENGALURU (KARNATAKA) INDIA

Email : bslaxmeshwar@gmail.com

\section{-ABSTRACT}

The purpose this study was to compare the attitude of rural and urban high school boys of Haveri district towards physical education and sports. A sample of 50-urban and 50-rural high school boys were surveyed using of ADAM'S ATTITUDE QUESTIONAIRE for the purpose. The aggregate score for each subject was computed as suggested by Adams. The data was subjected to ' $t$ ' test using SPSS (V-21 statistical package). The study revealed that there is a significant difference between urban and rural school-boys. It was concluded that the urban school boys of Haveri district have a significantly better attitude towards physical education and sports than rural boys.

- KEY WORDS : Attitude, Rural, Urban, Physical education

- HOW TO CITE THIS PAPER : Laxmeshwar, Basanangouda (2015). A comparative study of rural and urban high-school boys attitude towords physical education and sports of Haveri disrtict. Internat. J. Phy. Edu., 8 (2) : 91-93. 